\title{
Tactical Communications Research and Development Requirements from Signal and Behavioral Science Perspectives
}

\author{
Dorothy L. Finley
}

U.S. Army Research Institute

\section{Armored Forces Research Unit Barbara A. Black, Chief}

\section{U.S. Army Research Institute for the Behavioral and Social Sciences 5001 Eisenhower Avenue, Alexandria, Virginia 22333-5600 \\ Office, Deputy Chief of Staff for Personnel \\ Department of the Army}

\section{June 1997}

